\title{
Canadian Interests in Forest Products Trade
}

\author{
by
}

\author{
Honourable James Kelleher, PC, MP
}

\begin{abstract}
The international market environment for forest products has become more competitive. This has resulted from slower growth in demand and increased capacity of producers in importing countries to meet domestic requirements. Exports have also increased from new producing countries. These problems coupled with the much slower recovery of overseas markets have led to conditions of oversupply. Against this background protectionist pressures have grown, particularly against our softwood lumber exports to the United States. It will therefore be important to secure market access for our forest products and reduce remaining trade barriers to allow competitive adjustment of our forest industries. Marketing initiatives will also be required to realize new market opportunities and facilitate increased exports of further processed products. The National Trade Strategy will be a key vehicle in promoting our trade objectives in the sector.
\end{abstract}

\section{Introduction}

Economic renewal is a central objective of the Government of Canada. Trade is key to that objective and our forest industries will have a major role to play through improved export performance. The facts are well known both to industry and to government, but they perhaps bear rehearsing as a preface to the specific points I propose to address in this paper: the international context for trade in Canadian forest products and initiatives through which our government will address our trade interests in the sector.

Forest products represent a large segment of industrial activity in all regions of our country and account for a quarter of all jobs in Canadian manufacturing. The forest industries depend heavily on exports which represent about half of total sales in the sector. In 1984, exports of forest products were valued at $\$ 15.5$ billion, accounting for $14 \%$ of Canada's merchandise exports. In contrast, forest product imports were only $\$ 1.6$ billion in that year. Forest products, therefore, have an important place in Canada's National Trade Strategy.

The National Trade Strategy, which we have been pursuing since the First Ministers Conference in Regina in February 1985, has three fundamental objectives: improved trade competitiveness; secure and enhanced access to world markets; and more effective international marketing. Let us look at these objectives as they apply to the forest industries.

\section{International Market Conditions and Competitiveness}

For several years now, the international market environment for forest products has been becoming increasingly competitive. the factors are numerous: product oversupply, slower growth in demand, new producers and, for Canada, adverse exchange rates in relation to European currencies. They are well known but I shall review them briefly as a basis for future monitoring and assessment.

Despite significant recovery of markets since the recession of 1981-82, particularly in North America, demand has been growing at lower rates than those attained in earlier decades. For wood products, new housing construction requirements have grown more slowly in response to a decline in population growth, although the slowdown has been partly offset by recent declines in interest rates and increases in demand for housing renovation and repair in some countries. In pulp and paper, consumption has also grown at reduced rates, particularly for wood pulp in overseas markets. The trend towards greater office automation has negatively affected consumption of some paper products - but it has enhanced opportunities for others such as computer papers and business forms. Markets for other grades of paper have remained buoyant. in particular, exports of groundwood printing papers have grown rapidly to meet demands for newspaper inserts, catalogues and advertising circulars.

World markets for commodity grades of forest products (newsprint, pulp and lumber), of which Canada is a major exporter, are in various degrees of oversupply. In traditional importing countries, competition from domestic products has increased. In lumber, the problem has been compounded for producers in Canada by the slow recovery of overseas markets following the recession of 1981-82.

The continuing high rate of exchange of the Canadian dollar against European currencies has greatly affected the competitiveness of our exports in overseas markets. In particular, this has benefited Scandinavian producers and, taken together with earlier devaluation in their currencies, has greatly enhanced their ability to compete with Canadian exporters in Europe and, to some extent, the United States.

Finally, new producing countries are exporting to markets previously supplied by Canadian and other producers. This has particularly affected markets for wood pulp. Hardwood pulps, from Brazil and other countries with fast-growing forest plantations, are finding increasing acceptance as substitutes for higher quality paper-grade softwood pulps. 
Along with industry, the government has been closely monitoring developments in forest products trade. We will be tasking our missions abroad increasingly to provide the kind of reporting that can best complement industry sources. We will be giving increased attention to trade policy issues, market intelligence, structural adjustment programs, resource sector investment and the whole range of legislative, regulatory and corporate developments relevant to forest products development and trade abroad. We will, moreover, participate actively in relevant multilateral and bilateral fora, including the new International Tropical Timber Organization, which Cabinet has recently taken the decision to join.

\section{Market Access and Government Initiatives}

With growing competition in world markets, protectionist pressures have risen against our exports in many sectors including forest products. The most notable, of course, are the various legislative proposals currently before the US Congress to limit imports of our softwood lumber - all despite the fact that the US Department of Commerce concluded after a countervailing duty investigation in 1983 that Canadian timber is not subsidized and is, therefore, not a source of unfair competition to producers in the United States. Producers of shingles and shakes in the northwestern United States also are seeking temporary import relief under US trade law against Canadian exports. We are attempting in meetings with officials of the US Administration to resolve our trade problems in lumber and are, of course, prepared to make representations, as appropriate, to the Administration concerning our interest in the import relief action against Canadian shingles and shakes.

At the same time, the Prime Minister has announced the government's decision to pursue a new trade agreement with the United States and we are awaiting the Congressional response. Our objectives in that context are: 1) assured and stable access for our exports, 2) reduction of remaining trade barriers, and 3) a better framework of rules for settlement of trade disputes. It is our view that Canadian industrial expansion and modernization would benefit from greater certainty regarding the application of trade laws in the United States. We also recognize that certain domestically oriented industries will require a transition period to adjust to a more liberalized trading environment which could result from such negotiations.

While the growth in protectionist pressures emphasizes the need to secure sustained and enhanced access for forest products in our major market, we are also placing priority on improving access, particularly for further processed products and in overseas markets where significant trade barriers remain. In the European Community, tariffs apply to imports of planed lumber, ex-quota shipments of plywood and newsprint and on other paper and paperboard. In the EC, Scandinavian producers benefit from unlimited duty-free access by virtue of their industrial free trade agreements with the Community. In addition, Canadian exports face non-tariff measures such as phytosanitary requirements, product standards and building codes. In Japan, the high tariff on imports of planed sprucepine-fir lumber, the major lumber species produced in Canada, is a major restriction on Canadian exports. Despite successful Canadian efforts to convince Japan to adopt a platform frame construction system and a PFC standard for softwood plywood in its building codes, restrictions on the use of wood in buildings over $2 \frac{1}{2} 2$-storeys are problems that we are continuing to pursue. Tariffs and other trade barriers also limit our exports to a number of markets, including Korea and Australia.

For these reasons, Canada was an early proponent of another round of multilateral trade negotiations under the GATT and we are committed to ensuring their success. As I announced on July 19, 1985 we will be seeking in those negotiations "to open further markets for Canadian exports, to enhance security of access to those markets and to improve international trade rules." These objectives are central to our interests in forest products trade, and work is already underway to identify our specific goals for the sector.

In this regard, I have established an advisory system, in which the forest products sector will be represented, to provide advice to the government on trade. I will shortly be announcing the composition of a sectoral advisory group on forest products as part of the system. This group will address trade access and marketing issues in the forest products sector. It will also advise the government on Canadian objectives, priorities and strategies for multilateral and bilateral trade policies and negotiations as they relate to forest products.

\section{Marketing}

Market development efforts will be needed to meet new market opportunities and to encourage exports of further processed forest products. Development of new markets would allow our forest industries to broaden and diversify sales and lessen their vulnerability to cyclical fluctuations in North American markets. The government, therefore, supports the efforts of Canadian exporters to pursue new opportunities for expanding sales in Asia-Pacific countries, the Middle East, the Caribbean and South and Central America.

At the same time our industries are rightly emphasizing development of markets for higher-valued products such as joinery grades and specialty wood products from Canadian lumber. Such efforts could also assist Canadian producers in regions most affected by higher delivered wood costs in adjusting to more efficient and competitive production from available timber supplies.

Our trade officials in Ottawa, regional offices in Canada and our embassies abroad will continue to be available to assist Canadian forest products exporters in their marketing. As part of the National Trade Strategy we are seeking to develop more effective marketing support programs and have been inviting industry views in this regard. In addition, the Cooperative Overseas Market Development Program (COMDP) - a program jointly funded by the federal government (through the Department of Regional Industrial Expansion), the Province of British Columbia and the Council of Forest Industries of British Columbia - has been renewed for a fourth five-year term to promote overseas exports of wood products from British Columbia. A similar program was initiated in 1985 in Quebec.

\section{Conclusions}

Canadian trade objectives being pursued in several initiatives, principally under the National Trade Strategy, would facilitate adjustment of our industries to the more competitive international trading environment for forest products. Those objectives include: 1) assured access for our 
exports against protectionist pressures; 2) removal of remaining trade barriers; 3 ) improved procedures for settling trade disputes; 4 ) provision for an adequate transition period for adjustment of more domestically oriented subsectors of Canadian industry to a more liberalized trading environment; and 5) more effective marketing support in pursuing opportunities for increased export sales and development of markets for higher-valued products. Continuing efforts by Canadian forest industries, in improving production costs in relation to competing producers, would also be required to enhance trade performance. 